\title{
Restriction of Host Range by the sym2 Allele of Afghan Pea Is Nonspecific for the Type of Modification at the Reducing Terminus of Nodulation Signals
}

\author{
Alexandra O. Ovtsyna, ${ }^{1,2}$ Rene Geurts, ${ }^{3}$ Ton Bisseling, ${ }^{3}$ Ben J. J. Lugtenberg, ${ }^{1}$ Igor A. Tikhonovich, ${ }^{2}$ \\ and Herman P. Spaink ${ }^{1}$ \\ ${ }^{1}$ Institute of Molecular Plant Sciences, Clusius Laboratory, Leiden University, Wassenaarseweg 64, $2333 \mathrm{AL}$ \\ Leiden, The Netherlands; ${ }^{2}$ All-Russia Research Institute for Agricultural Microbiology, Podbelsky shosee \\ 3, 189620 St. Petersburg - Pushkin - 8, Russia; ${ }^{3}$ Department of Molecular Biology, Agricultural University, \\ Dreijenlaan 3, $6703 \mathrm{HA}$, Wageningen, The Netherlands \\ Accepted 29 January 1998.
}

\begin{abstract}
Rhizobium leguminosarum bv. viciae strains producing lipo-chitin oligosaccharides (LCOs) that are O-acetylated at the reducing terminus are required for nodulation of wild pea cultivars originating from Afghanistan that possess the recessive $\operatorname{sym}^{A}$ allele. The $O$-acetylation of the reducing sugar of LCOs is mediated by the bacterial nodX gene, which presumably encodes an acetyltransferase. We found that for nodulation on Afghan pea cultivars and $\operatorname{sym} 2^{A}$ introgression lines the $\operatorname{nod} X$ gene can be functionally replaced by the nodZ gene of Bradyrhizobium japonicum, which encodes a fucosyltransferase that fucosylates the reducing terminus of LCOs. The structure of the nodules, which were induced with normal frequency, was typical for effective pea nodules, and they fixed nitrogen with the same efficiency as nodules induced by nodX-carrying strains.
\end{abstract}

Within the cross-inoculation group of Rhizobium leguminosarum bv. viciae a cultivar specificity exists in that some primitive pea (Pisum sativum) cultivars originating from the Middle East (e.g., Afghanistan, Iran, Turkey, Israel; here, however, collectively called Afghan peas), are not nodulated by the ordinary European and North American strains but require $R$. leguminosarum bv. viciae strains from the Middle East for the symbiosis (Govorov 1928, 1937; Lie 1978). The resistance of Afghan peas to nodulation was found to be controlled by the $s y m 2^{A}$ allele, which is involved in early stages of the infection process (Geurts et al. 1997; Kozik et al. 1995; Lie 1984). R. leguminosarum bv. viciae strains able to nodulate Afghan peas were isolated first from soils of Turkey (e.g., strain TOM; Winarno and Lie 1979), and later from different

Corresponding author: Herman P. Spaink, Institute of Molecular Plant Sciences, Clusius Laboratory, Leiden University, Wassenaarseweg 64, 2333 AL Leiden, The Netherlands; Telephone: +31-71-5275055; Fax: +31-71-5275088; E-mail: Spaink@ rulbim.LeidenUniv.nl geographic regions of the world (Denmark, China, India, Morocco, Yugoslavia, Russia) (Ma and Iyer 1990). It was shown that the ability to nodulate Afghan peas in strain TOM is conferred by the nodX gene, which is located downstream of the nodABCIJ genes, indicating a gene-for-gene relationship (Davis et al. 1988; Geurts et al. 1997). The function of the host-specific gene nodX, which is present in all Rhizobium strains nodulating Afghan peas, is to O-acetylate lipo-chitin oligosaccharides (LCOs; also called Nod factors) at their reducing terminus (Firmin et al. 1993; Dénarié et al. 1996; Spaink 1996). As a consequence, it has become clear that the acetylation of the reducing terminus of Nod factor of $R$. leguminosarum bv. viciae is necessary to achieve infection on sym $2^{A}$-harboring peas, leading to successful nodulation (Firmin et al. 1993; Geurts et al. 1997; Kozik et al. 1995).

In order to test the structural requirements of Nod factors for nodulation of peas containing the $s y m 2^{A}$ allele, we have constructed a set of strains carrying additional nod genes on separate plasmids. As a uniform background for the introduction of nod genes, R. leguminosarum bv. viciae strain 248 was used, which nodulates European peas (homozygote $s y m 2^{C}$ ) efficiently but fails to nodulate pea lines homozygote for $\operatorname{sym} 2^{A}$. The following genes were introduced into strain 248 on plasmids of different incompatibility groups: the nodX gene from $R$. leguminosarum bv. viciae strain TOM, the nodZ gene from Bradyrhizobium japonicum, which links a fucosyl group to the reducing terminus of LCOs (Stacy et al. 1994; Quinto et al. 1997), and the regulatory gene nodD FITA (flavonoid independent transcription activation), which activates nod genes in the absence of flavonoids (Spaink et al. 1989). To check the influence of copy number of the plasmid, we have used plasmids pMW1071 and pMW2102, which contain the nodX gene on replicons of the IncP and IncW groups, respectively (Table 1). The presence of introduced nod genes in transconjugant strains was in all cases confirmed by thin layer chromatography of ${ }^{14} \mathrm{C}$-labeled LCOs as previously described (López-Lara et al. 1995; Spaink et al. 1995) and by 
polymerase chain reaction (data not shown). As expected, the introduction of nodD FITA gene into strain 248 resulted in the synthesis of LCOs even in the absence of inducer (data not shown).

To test whether the transconjugant strains are able to nodulate $\operatorname{sym} 2^{A}$-harboring peas, the two Afghan pea lines L2150 (also known as cv. Afghanistan) and L6559 and the $s y m 2^{A}$ introgression line 37(1)2 were inoculated in a gravel-based nodulation assay (Raggio and Raggio 1956). Line 37(1)2 resulted from crossing of the European line NGB1238 with the Afghan line L2150, followed by six to seven selfcrosses with selection of plants with nodulation-minus phenotype upon inoculation by European strains. Nodules were scored 3 weeks after inoculation (Table 2). The nodX-containing strains induced nodules on all pea lines tested. The copy number of the vector containing the $\operatorname{nodX}$ gene did not have a significant effect on nodulation. Surprisingly, strains that contained the $n o d Z$ gene also were able to elicit nodules on $s y m 2^{A}$-harboring peas. The wild-type pea lines and the introgression line 37(1)2 formed a slightly reduced number of nodules upon inoculation by strain 248 harboring only the nodZ gene, but when the nodD FITA gene was added, the number of nodules reached a value similar to that obtained after inoculation by nodXcarrying strains (Table 2). Furthermore, in the presence of the FITA nodD gene these lines formed larger nodules on the main root whereas without the FITA nodD gene the number of nodules on lateral roots was larger. The lower number of big nodules on a main root in case of the introduction of the nodZ gene alone might indicate some delay in nodulation leading to preferential formation of nodules on the lateral roots. A positive effect of the nodD FITA gene was not observed in the

Table 1. Bacterial strains and plasmids used in this study ${ }^{\mathrm{a}}$

\begin{tabular}{|c|c|c|}
\hline Strain or plasmid & Relevant characteristics & Source or reference \\
\hline \multicolumn{3}{|c|}{ Rhizobium leguminosarum } \\
\hline 248 & $\begin{array}{l}\text { R. leguminosarum bv. vi- } \\
\text { ciae wild type }\end{array}$ & Josey et al. 1979 \\
\hline 248 nodO::Tn5 & $\begin{array}{l}1391 \text { carrying } \\
\text { pRL1JInod } O_{94}:: \operatorname{Tn} 5\end{array}$ & Geurts et al. 1997 \\
\hline 1391 & $\begin{array}{l}248 \mathrm{Rif}^{\mathrm{r}} \text {, cured from its } \\
\text { plasmid pRL1JI }\end{array}$ & Schlaman et al. 1992 \\
\hline \multicolumn{3}{|l|}{ Plasmids } \\
\hline & $\begin{array}{l}\text { Sym plasmid of } R \text {. legumi- } \\
\text { nosarum bv. viciae strain } \\
248\end{array}$ & Johnston et al. 1978 \\
\hline pRK2013 & IncColE1, $\mathrm{Tra}^{+}, \mathrm{Km}^{\mathrm{r}}$ & Ditta et al. 1980 \\
\hline pMP604 & $\begin{array}{l}\text { IncP, contains nodD FITA, } \\
\mathrm{Tc}^{\mathrm{r}}\end{array}$ & Spaink et al. 1989 \\
\hline pMP1604 & $\begin{array}{l}\text { IncW, contains nodD FITA, } \\
\text { Spec }^{\mathrm{r}}\end{array}$ & López-Lara et al. 1996 \\
\hline pMP2450 & IncP, contains pA-nodZ, $\mathrm{Tc}^{\mathrm{r}}$ & López-Lara et al. 1996 \\
\hline pMW1071 & IncP, contains pA-nodX, $\mathrm{Tc}^{\mathrm{r}}$ & Kozik et al. 1995 \\
\hline pMW2102 & $\begin{array}{l}\text { IncW, contains pA-nodX, } \\
\text { Spec }^{\mathrm{r}}\end{array}$ & Geurts et al. 1997 \\
\hline
\end{tabular}

${ }^{a}$ Abbreviations: $\mathrm{Tc}^{\mathrm{r}}$, Specr, Rif ${ }^{\mathrm{r}}$, and $\mathrm{Km}^{\mathrm{r}}$ : tetracycline, spectinomycin, rifampicin, and kanamycin resistance, respectively; pA, promoter of nodA gene of $R$. leguminosarum bv. viciae; Inc, plasmid incompatibility group; nodO94:: $\mathrm{Tn} 5, \mathrm{Tn} 5$ mutation in the nodO gene; $\mathrm{Tra}^{+}$, region of conjugation transfer; Rlv, R. leguminosarum bv. viciae; nodD FITA (flavonoid independent transcription activation), hybrid nodD gene able to induce nod gene expression in the absence of flavonoids (Spaink et al. 1989). Rhizobial strains were grown on $\mathrm{B}^{-}$medium (van Brussel et al. 1977). Transconjugants were selected on $\mathrm{B}^{-}$media supplemented with $2 \mathrm{mg}$ of tetracycline per 1 for IncP plasmids or with $100 \mathrm{mg}$ of spectinomycin per 1 for IncW plasmids. case of the nodX-containing strains. The enhancement of nodulation, in case of co-introduction of nodD FITA with the nodZ gene, could be the result of overcoming a limited nod gene expression and subsequent Nod factor production. The strain harboring the combination of nodZ and nodX genes on separate plasmids displayed slightly decreased nodulation.

To determine the relative number of bacteria harboring plasmids inside the nodules, we have isolated bacteria from nodules and tested the frequency of antibiotic resistance. About 70 to $80 \%$ of isolated clones were resistant to the tested antibiotics. Since the IncP and IncW plasmids used in this study are lost relatively rapidly in the absence of antibiotics (data not shown) these results indicate that plasmids carrying $\operatorname{nod} X$ or nodZ genes conferred a selective advantage during the infection process.

The gene nod $O$ encodes a secreted protein that is not involved in LCO synthesis or secretion but it may partially compensate the lack of genes participating in LCO modification (Downie and Surin 1990; Economou et al. 1994; van Rhijn et al. 1996; Sutton et al. 1994). Wild-type strain 248, harboring an active nod $O$ gene, sporadically triggers infections on $\operatorname{sym} 2^{A}$ introgression lines, leading to the formation of functional nodules (Table 2), whereas a nodO mutant is absolutely unsuccessful in triggering successful infections (Geurts et al. 1997; Sutton et al. 1994). We have tested whether nodO contributes to the nodulation ability of the strains producing fucosylated Nod factors. To this end we introduced the plasmid pMP2450 carrying the nodZ gene into strain 248 with a defective nodO gene. The analysis of the NodO effect was performed with a nodulation assay in which the pea plants were grown on perlite instead of gravel. In this assay the number of nodules obtained is higher than on gravel, facilitating the detection of a nodO-related phenotype. The cultivar Rondo, homozygote for $s y m 2^{C}$, and the introgression line Rondo-sym $2^{A}$ were inoculated with the strains 248, 248.pMW1071 $(\operatorname{nod} X)$, and 248.pMP2450 $(\operatorname{nodZ})$ as well as with their nodO::Tn5 counterparts. Near-isogenic lines Rondo-sym $2^{C}$ (cv. Rondo) and the backcross line Rondo$s y m 2^{A}$ were described by Kozik et al. ( 1995). Introgression line Rondo-sym $2^{A}$ resulted from crossing of pea L2150 (cv. Afghanistan) to European cultivar Rondo-sym $2^{C}$ with subsequent three backcrosses to Rondo-sym $2^{C}$. This line contains less introgressed DNA of Afghan line L2150 when compared with line 37(1)2.

Nodules were scored 3 weeks after inoculation (Table 3). From the results of nodulation experiments it is apparent that in the presence of nod $O$ there is no difference in nodulation efficiency between the nodX-and the nodZ-harboring strains; 248 nodZ nodulates the Rondo-sym $2^{A}$ introgression line as efficiently as it does Rondo-sym $2^{C}$. In the absence of nod $O$, the nodZ-harboring strain was also able to elicit nodules on Rondo-sym $2^{A}$, although at a slightly lower frequency when compared with 248nodO::Tn5.pMW1071(nodX) (Table 3). Therefore, we can conclude that the presence of a fucosyl decoration at the $\mathrm{C} 6$ position of the reducing terminal glucosamine of the Nod factors is sufficient to overrule the block on nodulation independently from nod $O$.

Cross sections of mature nodules were examined by light microscopy. The structure of nodules induced by nodZ- and $n o d X$-harboring strains was very similar and typical for normal nitrogen-fixing nodules (Fig. 1A and B). Central tissue of 
the nodules representing the nitrogen-fixing zone had a dark color due to the presence of fully occupied, bacteroidcontaining cells (enlarged parenchyma cells whose cytoplasm was packed with bacteroids) (Fig. 1A and B). Bacteroidcontaining cells had a prominent central vacuole, which is typical for pea nodules. Beneath the endodermis, normal vascular bundle structures surrounding the central tissue are present (Fig. 1). To confirm that nitrogen fixation in nodules did take place, the acetylene reduction activity was measured with plants of the introgression line 37(1)2 as representative. The results show that nodules elicited on pea plants by nodX- and nodZ-carrying transconjugant strains were able to fix nitrogen with comparable efficiency (Table 2). The total nitrogenase activity correlated in general with the total number of nodules and was maximal in nodules elicited by the strains 248.pMW1071(nodX) and 248.pMP2450(nodZ).pMP1604(nodD FITA) (Table 2). The acetylene reduction activity in the negative control strains 248 and 248.pMP1604(nodD FITA) was relatively high, presumably since the very few nodules formed in these cases were very large. Thus, nodules elicited on sym $2^{A}$-harboring peas by nodZ-carrying strains are efficient nitrogen-fixing organs structurally indistinguishable from wild-type, nitrogen-fixing pea nodules.

In this work we have shown that fucosylation of the reducing terminus of Nod factors confers on the bacteria an ability to nodulate peas carrying the $s y m 2^{A}$ allele. The mechanism of Nod-factor perception by a leguminous host plant remains unclear. Basically, there could be two possible ways that a plant perceives LCOs, with different modifications. First, differently decorated LCOs may fit to different plant receptors. In this case, the stringent requirements for LCO structure should be dictated by more than one receptor. Second, different Nod factors might be recognized by the same receptor but their stability may vary depending on the host plant. There is evidence that decorations of Nod-factor backbone such as nodHmediated sulfation, nodEF-mediated acylation, and others may improve their stability against plant chitinases that cause degradation of LCO molecules (Staehelin et al. 1994). Our results show that in the case of Afghan peas ( $\operatorname{sym} 2^{A}$ allele) the requirements for LCO structures are not very strict, since apparently a fucosyl group can functionally replace the structurally different $O$-acetyl group for infection and nodulation. This observation is not in favor for the hypothesis of involve- ment of the modifications of the reducing terminus for specific receptor-ligand interaction, but it rather seems to support the second possibility: increased stability of LCOs toward plant chitinases. On the other hand, studies on the degradation rate of mono-acetylated Nod factors by European and Afghan peas did not reveal any differences in degrading activity between root exudates of $s y m 2^{A}$ - and $s y m 2^{C}$-containing lines, suggesting that Afghan peas do not possess specific chitinase activity that destroys monoacetylated LCOs faster than doubly acetylated LCOs. To get a better insight into the mechanisms of host range restriction by Afghan peas, it would be interesting to compare in more detail (preferably in situ) the relative stability of mono- and double-acetylated Nod factors toward degradation by plant enzymes in $s y m 2^{A}$ and $s y m 2^{C}$ homozygous backgrounds.

\section{ACKNOWLEDGMENTS}

We are very grateful to Gerda E. M. Lamers and Teun Tak for technical assistance. This work was supported by the Netherlands Organization for Scientific Research (NWO project no. 047.001-002 to B. J. J. L.), INTAS (project no. 94-.1058 to B. J. J. L.), HCM (project CHRX -

Table 3. Nodule formation on near-isogenic pea lines upon inoculation with Rhizobium strains harboring additional nod genes $^{\mathrm{a}}$

\begin{tabular}{lcc}
\hline $\begin{array}{l}\boldsymbol{R} \text {. leguminosarum bv. viciae } \\
\text { strain/plasmid }\end{array}$ & ${\text { Rondo-sym } 2^{\boldsymbol{A}}}$ & Rondo-sym2 $^{\boldsymbol{C}}$ \\
\hline 248 & $2 \pm 1(\mathrm{n}=8)$ & $50 \pm 4(\mathrm{n}=8)$ \\
248.pMW1071(nodX) & $51 \pm 4(\mathrm{n}=8)$ & $50 \pm 5(\mathrm{n}=8)$ \\
248.pMP2450(nodZ) & $50 \pm 4(\mathrm{n}=8)$ & $48 \pm 2(\mathrm{n}=7)$ \\
248nodO::Tn5 & $0(\mathrm{n}=18)$ & $46 \pm 2(\mathrm{n}=18)$ \\
248nodO::Tn5.pMW1071(nodX) & $51 \pm 4(\mathrm{n}=18)$ & $41 \pm 3(\mathrm{n}=18)$ \\
248nodO::Tn5.pMP2450(nodZ) & $28 \pm 2(\mathrm{n}=18)$ & $45 \pm 3(\mathrm{n}=17)$ \\
\hline
\end{tabular}

${ }^{a}$ Deviations are given for the number of plants indicated. Use was made of a perlite-based assay. For this assay, pea seeds were surface sterilized (15 min commercial bleach, $15 \mathrm{~min} 7 \% \mathrm{H}_{2} \mathrm{O}_{2}$, thoroughly washed several times with sterile water) and sown in modified Leonard jars, which consist of a plastic (coffee) beaker of about $100 \mathrm{ml}$ filled with perlite (Lie et al. 1988). This beaker is put into a $360-\mathrm{ml}$ preservation jar, which serves as the reservoir for the nutrient solution (Fahraeus 1957). A foam plastic wick is inserted through a slit made in the bottom of the beaker. Before use, the Leonard jars were kept for 5 days at $70^{\circ} \mathrm{C}$. After sowing, the pea seeds were inoculated with $2 \mathrm{ml}$ of freshly grown rhizobia of $\mathrm{OD}_{620}=0.1$, and covered with a layer of sterilized, fine gravel to prevent contamination.

Table 2. Number of nodules and levels of nitrogen fixation in wild-type Afghan and sym $2^{A}$ introgression pea lines inoculated with isogenic Rhizobium leguminosarum bv. viciae strains $^{\mathrm{a}}$

\begin{tabular}{|c|c|c|c|c|}
\hline \multirow[b]{2}{*}{ R. leguminosarum bv. viciae strain/plasmid } & \multicolumn{2}{|c|}{ Afghan pea line } & \multirow{2}{*}{$\begin{array}{c}\text { Introgression line } \\
\mathbf{3 7 ( 1 ) 2}\end{array}$} & \multirow{2}{*}{$\begin{array}{l}\text { Acetylene reduction } \\
(\mu \mathrm{Mol} / \text { plant })\end{array}$} \\
\hline & $\mathbf{L 2 1 5 0}$ & L6556 & & \\
\hline 248 & 0 & 0 & $1 \pm 1$ & 2.3 \\
\hline 248.pMP1604 (nodD FITA) & 0 & 0 & $2 \pm 2$ & 3.4 \\
\hline 248.pMW1071 (nodX) & $9 \pm 3$ & $9 \pm 2$ & $16 \pm 8$ & 20.6 \\
\hline 248.pMW1071 (nodX).pMP1604 (nodD FITA) & $11 \pm 2$ & $5 \pm 2$ & $19 \pm 8$ & 9.2 \\
\hline 248.pMW2102 (nodX) & $11 \pm 2$ & $2 \pm 1$ & $20 \pm 7$ & 15 \\
\hline 248.pMW2102 (nodX) .pMP604 (nodD FITA) & $6 \pm 1$ & $7 \pm 2$ & $13 \pm 6$ & 12 \\
\hline 248.pMP2450 (nodZ) & $8 \pm 2$ & $7 \pm 2$ & $5 \pm 1$ & 7.6 \\
\hline 248.pMP2450 (nodZ).pMP1604 (nodD FITA) & $15 \pm 2$ & $15 \pm 5$ & $22 \pm 6$ & 15.9 \\
\hline 248.pMP2450 (nodZ).pMW2102 (nodX) & $6 \pm 1$ & $2 \pm 1$ & $15 \pm 6$ & 6.8 \\
\hline
\end{tabular}

${ }^{a}$ Nitrogen fixation data was obtained with introgression line 77(1)2. A minimum of six plants were grown in grown in a gravel-based assay. For this assay seeds of pea (Pisum sativum L.) were surface sterilized for 5 to $7 \mathrm{~min}$ in concentrated sulfuric acid, thoroughly washed several times with sterile water, and allowed to germinate on minimal medium solidified with agar. Three-day-old seedlings were transferred into sterile 5-1 glass beakers filled with red gravel and watered with Raggio nutrient solution (Raggio and Raggio 1956). Each pea plant was inoculated with $500 \mathrm{ml}$ of a suspension of the freshly grown rhizobia in Jensen medium (van Brussel et al. 1982) diluted up to an $\mathrm{OD}_{620}$ value of 0.1 . 

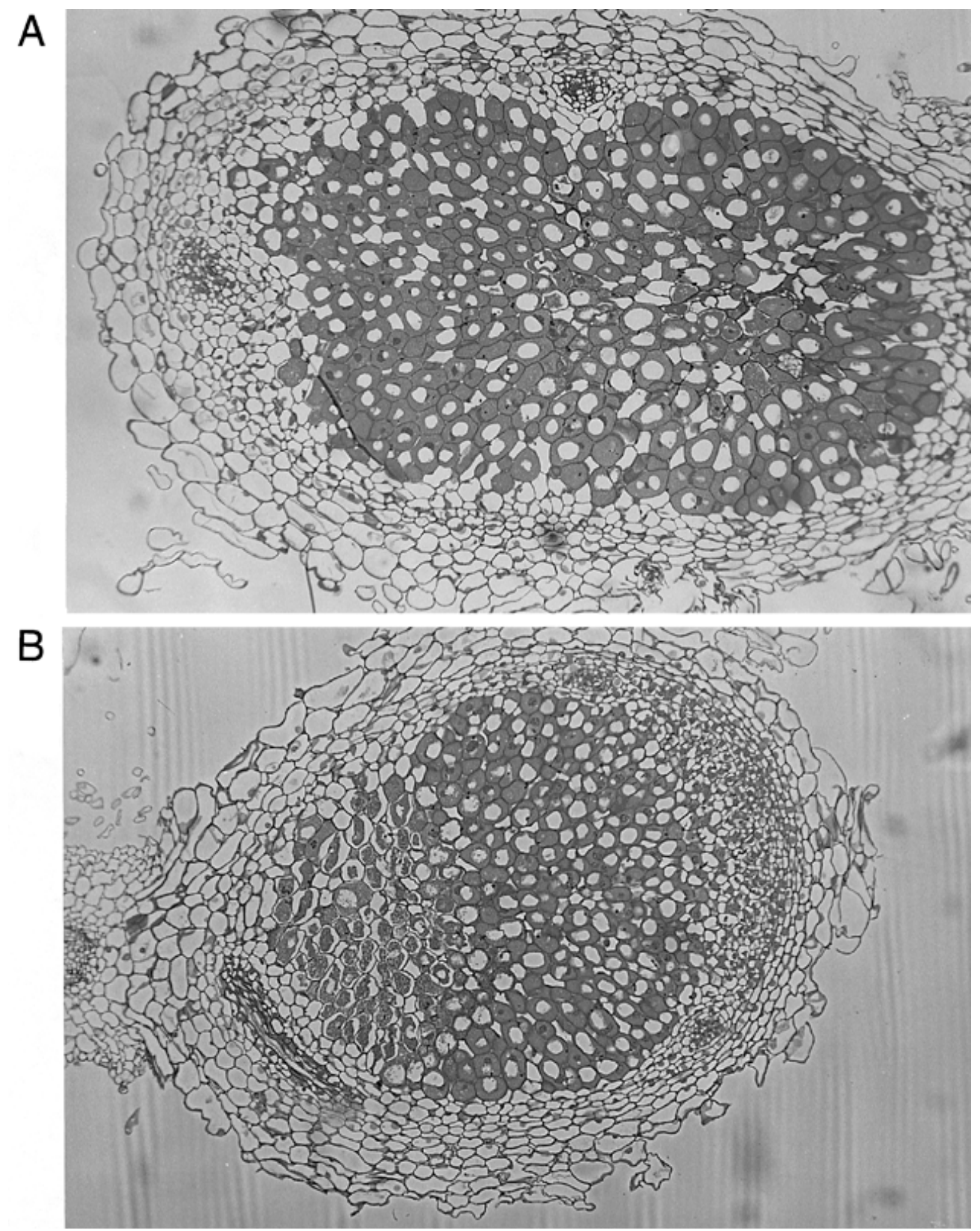

Fig. 1. Cross sections of mature pea nodules elicited on Afghan pea line L2150 by (A) nodZ-and (B) nodX-harboring derivatives of Rhizobium leguminosarum strain 248 . The central tissue of the nodules representing the nitrogen-fixing zone is occupied by bacteroid-containing cells. Nodulation assays were performed as described previously (Hooykaas et al. 1977; van Brussel et al. 1982). 
CT94 -0656 to H. P. S.), and NWO - PIONIER (to H. P. S.) grants. Seeds of pea lines of Afghan (L2150 [other name "cv. Afghanistan"] and L6559) and European origin (L32), and the $s y m 2^{A}$ introgression line 37(1)2 were kindly provided by O. A. Kulikova (All- Russia Research Institute for Agricultural Microbiology).

\section{LITERATURE CITED}

Davis, E. O., Evans, I. J., and Johnston, A. W. B. 1988. Identification of $\operatorname{nodX}$, a gene that allows Rhizobium leguminosarum biovar viciae strain TOM to nodulate Afghanistan peas. Mol. Gen. Genet. 212:531535.

Dénarié, J., Debellé, F., and Promé, J. C. 1996. Rhizobium lipochitooligosaccharide nodulation factors: Signaling molecules mediating recognition and morphogenesis. Ann. Rev. Biochem. 65:503535.

Ditta, G., Stanfield, S., Corbin, D., and Helinski, D. R. 1980. Broad host-range DNA cloning system for gram-negative bacteria: Construction of a gene bank of Rhizobium meliloti. Proc. Natl. Acad. Sci. USA 77:7347-7351.

Downie, J. A., and Surin, B. P. 1990. Either of two nod gene loci can complement the nodulation defect of a nod deletion mutant of Rhizobium leguminosarum bv viciae. Mol. Gen. Genet. 222:81-86.

Economou, A., Davies, A. E., Johnston, A. W. B., and Downie, J. A. 1994. The Rhizobium leguminosarum biovar viciae nodO gene can enable a nodE mutant of Rhizobium leguminosarum biovar trifolii to nodulate vetch. Microbiology 140:2341-2347.

Fahraeus, G. 1957. The infection of clover root hairs by nodule bacteria studied by a simple glass slide technique. J. Gen. Microbiol. 32:374381.

Firmin, J. L., Wilson, K. E., Carlson, R. W., Davies, A. E., and Downie, J. A. 1993. Resistance to nodulation of cv Afghanistan peas is overcome by $\operatorname{nod} X$ which mediates an $O$-acetylation of the Rhizobium leguminosarum lipo-oligosaccharide nodulation factor. Mol. Microbiol. $10: 351-360$

Geurts, R., Heidstra, R., Hadri, A.-E., Downie, A., Franssen, H., van Kammen, A., and Bisseling, T. 1997. Sym2 of Pisum sativum is involved in a Nod factor perception mechanism that controls the infection process in the epidermis. Plant Physiol. 115:351-359.

Govorov, L. I. 1928. The peas of Afghanistan. Bull. Appl. Bot. Genet. Plant Breed. 19:497-522.

Govorov, L. I. 1937. Peas. Pages 231-336 in: Flora of Cultivated Plants. Vol. 4. N. I. Vavilov and E. V. Wulff, eds. Kolos, Leningrad.

Hooykaas, P. J. J., Klapwijk, P. M., Nuti, M. P., Schilperoort, R. A., and Rörsch, A. 1977. Transfer of the Agrobacterium Ti plasmid to avirulent agrobacteria and to rhizobia ex planta. J. Gen. Microbiol. 98:477-484.

Johnston, A. W. B., Beynon, J. L., Buchanon-Wollaston, A. V., Setchell, S. M., Hirsch, P. R., and Beringer, J. E. 1978. High frequency transfer of nodulation ability between strains and species of Rhizobium. Nature (London) 276:634-636.

Josey, D. P., Beynon, J. L., Johnston, A. W. B., and Beringer, J. E. 1979. Strain identification in Rhizobium using intrinsic antibiotic resistance. J. Appl. Bacteriol. 46:343-350.

Kozik, A., Heidstra, R., Horvath, B., Kulikova, O., Tikhonovich, I., Ellis, T. H. N., van Kammen, A., Lie, T. A., and Bisseling, T. 1995. Pea lines carrying sym 1 or sym 2 can be nodulated by Rhizobium strains containing nodX; sym1 and sym2 are allelic. Plant Sci. 108:41-49.

Lie, T. A. 1978. Symbiotic specialization in pea plants: The requirement of specific Rhizobium strains for peas from Afghanistan. Ann. Appl. Biol. 88:462-465.

Lie, T. A. 1984. Host genes in Pisum sativum L. conferring resistance to European Rhizobium leguminosarum strains. Plant Soil 82:415-425.

Lie, T. A., Pijnenborg, J., and Timmermans, P. C. J. M. 1988. Analysis of the host genes controlling the legume - Rhizobium symbiosis: Some technical problems and pitfalls. Pages 93-100 in: Nitrogen Fixation by Legumes in Mediterranean Agriculture. D. P. Beck and L.
A. Materon, eds. Nijhoff, Dordrecht, The Netherlands.

López-Lara, I. M., Blok-Tip, L., Quinto, C., Garcia, M. L., Stacey, G., Bloemberg, G. V., Lamers, G. E. M., Lugtenberg, B. J. J., ThomasOates, J. E., and Spaink, H. P. 1996. NodZ of Bradyrhizobium extends the nodulation host range of Rhizobium by adding a fucosyl residue to nodulation signals. Mol. Microbiol. 21:397-408.

López-Lara, I. M., van den Berg, J. D. J., Thomas-Oates, J. E., Glushka, J., Lugtenberg, B. J. J., and Spaink, H. P. 1995. Structural identification of the lipo-chitin oligosaccharide nodulation signals of Rhizobium loti. Mol. Microbiol. 15:627-638.

Ma, S.-W., and Iyer, V. N. 1990. New field isolates of Rhizobium leguminosarum biovar viciae that nodulate the primitive pea cultivar Afghanistan in addition to modern cultivars. Appl. Environ. Microbiol. 56:2206-2212.

Quinto, C., Wijfjes, A. H. M., Bloemberg, G. V., Blok-Tip, L., LópezLara, I. M., Lugtenberg, B. J. J., Thomas-Oates, J. E., and Spaink, H. P. 1997. Bacterial nodulation protein NodZ is a chitin oligosaccharide fucosyltransferase which can also recognize related substrates of animal origin. Proc. Natl. Acad. Sci. USA 94:4336-4341.

Raggio, N., and Raggio, M. 1956. Relacion entre cotiledones y nodulacion y factores que la afectan. Phyton (Argentina) 7:103-119.

Roche, P., Debellé, F., Maillet, F., Lerouge, P., Faucher, C., Truchet, G., Dénarié, J., and Promé, J. C. 1991. Molecular basis of symbiotic host specificity in Rhizobium meliloti: nodH and nodPQ genes encode the sulfation of lipooligosaccharides signals. Cell 67:1131-1143.

Schlaman, H. R. M., Okker, R. J. H., and Lugtenberg, B. J. J. 1992. Regulation of nodulation gene expression by NodD in Rhizobia. J. Bacteriol. 174:5177-5182.

Spaink, H. P. 1996. Regulation of plant morphogenesis by lipo-chitin oligosaccharides. Crit. Rev. Plant Sci. 15:559-582.

Spaink, H. P., Bloemberg, G. V., van Brussel, A. A. N., Lugtenberg, B. J. J., van der Drift, K. M. G. M., Haverkamp, J., and Thomas-Oates, J. E. 1995. Host specificity of Rhizobium leguminosarum is determined by the hydrophobicity of highly unsaturated fatty acyl moieties of the nodulation factors. Mol. Plant-Microbe Interact. 8:155-164.

Spaink, H. P., Okker, R. J. H., Wijffelman, C. A., Tak, T., GoosendeRoo, L., Pees, E., van Brussel, A. A. N., and Lugtenberg, B. J. J. 1989. Symbiotic properties of rhizobia containing a flavonoid- independent hybrid nodD product. J. Bacteriol. 171:4045-4053.

Stacey, G., Luka, S., Sanjuan, J., Banfalvi, Z., Nieuwkoop, A. J., Chun, J. Y., Forsberg, L. S., and Carlson, R. 1994. NodZ, a unique hostspecific nodulation gene, is involved in the fucosylation of the lipooligosaccharide nodulation signal of Bradyrhizobium japonicum. J. Bacteriol. 176:620-633.

Staehelin, C., Schultze, M., Kondorosi, E., Mellor, R. B., Boller, T., and Kondorosi, A. 1994. Structural modifications in Rhizobium meliloti Nod factors influence their stability against hydrolysis by root chitinases. Plant J. 5:319-330.

Sutton, J. M., Lea, E. J. A., and Downie, J. A. 1994. The nodulationsignaling protein NodO from Rhizobium leguminosarum biovar viciae forms ion channels in membranes. Proc. Natl. Acad. Sci. USA 91: 9990-9994.

van Brussel, A. A. N., Planqué, K., and Quispel, A. 1977. The wall of Rhizobium leguminosarum in bacteroid and free-living forms. J. Gen. Microbiol. 101:51-56.

van Brussel, A. A. N., Tak, T., Wetselaar, A., Pees, E., and Wijffelman, C. A. 1982. Small leguminosae as test plants for nodulation of Rhizobium leguminosarum and other Rhizobia and Agrobacteria harbouring a leguminosarum plasmid. Plant Sci. Lett. 27:317-325.

van Rhijn, P., Luyten, E., Vlassak, K., and Vanderleyden, J. 1996. Isolation and characterization of a pSym locus of Rhizobium sp. BR816 that extends nodulation ability of narrow host range Phaseolus vulgaris symbionts to Leucaena leucocephala Mol. Plant-Microbe Interact. 9:74-77.

Winarno, R., and Lie, T. A. 1979. Competition between Rhizobium strains in nodule formation: Interaction between nodulating and nonnodulating strains. Plant Soil 51:135-142. 